\title{
INTERAKSI GURU DENGAN ORANG TUA SISWA ERA PERANG DAN DAMAI DI ACEH
}

\author{
Saifuddin \\ Universitas Malikussaleh Lhokseumawe Aceh, Indonesia \\ E-mail: saifuddin_my@yahoo.com
}

\begin{abstract}
The aim of the research is to analyze social interactions between teachers and parents during the era of war and peace in Aceh. This study employs qualitative method. During the war, the educational institution was one of the institutions which was affected badly. Social integration was so weak that interactions among parents of students, teachers and students were unstable. Within the war situation, social interactions were badly influenced hatred, suspicion, and revenge. The social interaction outside the school was contagious to that inside the school. But when the peace memorandum was signed on August 15, 2005, between the Indonesian government and Independence Aceh Movement (GAM), social interactions in schools began to show significant changes. When the war ended, people began to interact and socialize in good faith. Social interactions involving parents of students and teachers were also changing towards social stability and harmony so that they could interact without the feelings of fear, suspicion and revenge. Peace accord means that the enmity has significantly reduced. Hence, the teachers are effectively playing their fundamental role in teaching and socializing the younger generation of Acehnese.
\end{abstract}

Keywords: Interaction of teachers and parent; war and peace time; social stability and harmony.

\section{Pendahuluan}

Peperangan yang terjadi di negara-negara dunia pada umumnya berawal dari adanya kepincangan antara sumber daya alam yang melimpah dan minimnya sumber daya manusia. Keadaan tersebut melahirkan ketidakadilan ekonomi dan kecemburuan sosial, sehingga mendorong lahirnya pergolakan sosial dan pemberontakan bersenjata. Perang yang terjadi di Aceh adalah dampak dari kegagalan pihak-pihak yang berkonflik dalam menyelesaikan persoalan mereka secara aman 
melalui meja perundingan. Institusi pendidikan merupakan salah satu institusi sosial yang terkena dampak negatif dari konflik dan peperangan yang terjadi selama 30 tahun di Aceh (1976-2005).

Dampak yang ditimbulkan oleh peperangan terhadap institusi pendidikan di Aceh tidak terbatas pada persoalan fisik semata, akan tetapi dampak yang lebih besar adalah terhadap interaksi sosial yang melibatkan sejumlah para pendidik, para pelajar dan orang tua mereka. Kesan adanya gejolak emosi terjadi pada para siswa, terutama siswa Sekolah Lanjutan Tingkat Atas (SLTA). Tidak sedikit siswa yang terlibat secara langsung dalam proses konflik. Hal ini mengakibatkan terbentuknya sikap negatif para siswa terhadap proses pendidikan mereka. Fenomena tersebut mempertegas bahwa perang Aceh (19762005) telah memberikan dampak negatif terhadap institusi pendidikan di Aceh. ${ }^{1}$

Selama terjadinya peperangan, ketakutan menjadi dasar interaksi sosial masyarakat Aceh dengan militer. Lebih jauh, interaksi antara orang Aceh dengan orang non-Aceh (para pendatang) diwarnai oleh kecurigaan, sehingga menyebabkan hubungan antar-suku terganggu. Sebagai contoh, suku Jawa transmigran yang sudah lama tinggal di Aceh terpaksa berpindah tempat ke Medan (Sumatera Utara) bahkan ada yang kembali ke Pulau Jawa karena merasa tidak aman dengan kondisi sosial di Aceh. Suhu politik yang terus memanas selama terjadinya peperangan juga telah mengakibatkan sistem demokrasi dan pemerintahan di Aceh menjadi lumpuh. Semua itu menunjukkan bahwa peperangan telah memberikan dampak yang luar biasa terhadap kehidupan sosial masyarakat di Aceh.

Interaksi antara guru dengan orang tua siswa, guru dengan pelajar, pelajar dengan pelajar merupakan hal yang pasti terjadi dalam proses belajar mengajar. Interaksi guru dengan murid merupakan fondasi penting dalam proses pendidikan. Sekolah-sekolah dibangun bertujuan untuk mempersiapkan peserta didik dalam menghadapi dunia orang dewasa kelak. Tercapai atau tidak tujuan tersebut sangat tergantung pada mutu atau kualitas interaksi antara guru dengan murid. ${ }^{2}$ Realitas yang terjadi di Aceh justru bertolakbelakang dengan idealitas tersebut.

\footnotetext{
1 Saifuddin, Kesan Perang Terbadap Institusi Pendidikan (Bangi: Universiti Kebangsaan Malaysia, 2005), 95.

${ }^{2}$ Sharifah Alwiyah Alsagoff, Sosiologi Pendidikan (Petaling Jaya: Logman, 1988), 132.
} 
Perang yang berlangsung dalam waktu yang lama di Aceh telah menyebabkan sebagian pelajar hidup tanpa bimbingan guru dan perlindungan orang tua. Keadaan perang telah menyebabkan pelajar di Aceh terpaksa berpisah dengan orang tua, bahkan banyak orang tua mereka yang menjadi korban perang. Sebagian orang tua yang masih hidup berada dalam kondisi kesulitan ekonomi untuk mencari nafkah sehingga hal tersebut berdampak terhadap biaya pendidikan anak-anak mereka.

Peperangan di Aceh juga memberikan dampak negatif terhadap institusi pendidikan. Banyak sekolah di Aceh Timur terpaksa ditutup selama beberapa bulan, bahkan ada sekolah yang dibakar. Proses belajar-mengajar dihentikan. Namun demikian para siswa terpaksa diluluskan dalam ujian akhir meskipun tidak mampu menjawab soal ujian dengan baik. Hal ini terjadi karena adanya intervensi orang tua siswa (wali murid) terhadap guru di sekolah. Hal inilah yang, antara lain, menyebabkan interaksi antara guru dan orang tua siswa pada era perang mengalami permasalahan.

Penelitian mengenai dampak perang terhadap pendidikan di Aceh sendiri pernah dilakukan oleh banyak peneliti dan semuanya menunjukkan dampak negatif peperangan terhadap masyarakat. ${ }^{3}$ Setelah Aceh ditimpa musibah gempa dan Tsunami pada tanggal 26 Desember 2004, kondisi sosial politik di Aceh mengalami perubahan. Tsunami yang terjadi di Aceh menyebabkan perhatian dunia terhadap Aceh semakin kuat. Aceh mengalami dua musibah sekaligus, yaitu musibah karena konflik bersenjata yang lama dan musibah Tsunami. Oleh karena itu, masyarakat Asia bahkan dunia ingin membantu merehabilitasi dan merekonsruksi Aceh, namun dengan syarat Aceh harus terlebih dahulu berada dalam situasi aman, kondusif, dan damai.

Tsunami yang begitu dahsyat membuat pemerintah Indonesia tidak mungkin lagi menutup Aceh dari dunia luar. Ribuan tentara asing akhirnya masuk ke Aceh dalam masa darurat tiga bulan pertama Tsunami dan ratusan NGO serta badan-badan internasional lainnya sampai dengan Desember 2009 terus bekerja dalam berbagai program rehabilitasi dan rekonstruksi. Meskipun kebanyakan perhatian diarahkan kepada bantuan kemanusiaan dan pembangunan kembali Aceh pasca-Tsunami, namun jika konflik terus berlangsung maka akan

\footnotetext{
${ }^{3}$ Lebih lanjut lihat Saifuddin, Interaksi Sosial dalam Institusi Pendidikan Era Perang dan Damai di Aceh (Bangi: Universiti Kebangsaan Malaysia, 2013), 35.
} 
menjadi pertimbangan semua pihak yang ingin menyalurkan bantuannya di Aceh. ${ }^{4}$

Oleh karena itu, para pihak yang terlibat dalam konflik mulai memikirkan jalan terbaik untuk mengakhiri sengketa lama itu. Pemerintah Indonesia dan GAM lalu kembali ke meja perundingan untuk membahas perdamaian Aceh. Proses perdamaian di Aceh sendiri merupakan suatu proses yang penuh dengan tantangan serta menyita waktu yang lama untuk mencapai hasilnya. Berbagai pendekatan telah diterapkan oleh pemerintah untuk menyelesaikan konflik bersenjata di Aceh.

Pada masa pemerintahan Presiden Abdurrahman Wahid upaya dialog damai dengan nama Jeda Kemanusian I dan II telah dilakukan. Upaya ini dilanjutkan oleh Presiden Megawati Soekarnoputri namun pada akhirnya mengalami kegagalan, sehingga penyelesaian masalah Aceh menemui jalan buntu. Pendekatan diplomasi dalam penyelesaian konflik Aceh kembali digunakan oleh pemerintahan Presiden Susilo Bambang Yudhoyono dengan melakukan pembicaraan informal dengan pihak GAM. Pembicaraan informal yang berlangsung sejak akhir Januari 2005 sampai dengan Mei 2005 dilakukan dengan bantuan lembaga internasional Crisis Management Initiative (CMI) yang dipimpin oleh mantan presiden Finlandia Marti Atisari.

Rangkaian pembicaraan yang berlangsung lima tahap antara delegasi pemerintah RI dan GAM akhirnya menghasilkan sebuah nota kesepahaman atau Memorandum of Understanding ( $M o U$ ) yang ditandatangani pada tanggal 15 Agustus 2005 di Helsinki, Finlandia. ${ }^{5}$ Nota kesepahaman tersebut kemudian lebih dikenal dengan MoU Helsinki. MoU tersebut berisi kesepakatan dalam berbagai hal dan ia menjadi titik awal menuju babak baru kehidupan di Aceh. Konflik bersenjata dan proses perdamaian di Aceh telah memberi pelajaran yang berarti bagi rakyat Indonesia, terutama Pemerintah dan GAM.

Situasi sosial yang digambarkan di atas merupakan kondisi nyata yang dialami oleh masyarakat Aceh selama bertahun-tahun. Situasi dan kondisi tersebut mempengaruhi proses belajar mengajar atau proses sosialisasi dan interaksi sosial dalam institusi pendidikan di Aceh. Dari latar belakang di atas ada dua hal yang menjadi fokus pembahasan dalam tulisan ini, yaitu pertama bagaimana interaksi antara guru dengan

\footnotetext{
4 Ahmad Farhan Hamid, Jalan Damai Nanggroe Endatu: Catatan Seorang Wakil Rakyat Aceh (Jakarta: Suara Bebas, 2006), 162.

${ }^{5}$ Ibid., 230.
} 
orang tua siswa pada era perang di Aceh? Kedua, bagaiamana interaksi antara guru dengan orang tua siswa pada era damai di Aceh?

Kedua permasalahan tersebut di atas dianalisis secara sosiologis dengan menggunakan teori anomik Emile Durkheim. Dalam teori anomik yang dikemukan oleh Durkheim, penyebab bunuh diri adalah pengaruh dari integrasi sosial. Peristiwa bunuh diri merupakan kenyataan sosial yang dapat dikaji dengan menghubungkan struktur sosial dan tingkat integrasi sosial dari suatu kehidupan. ${ }^{6}$ Apabila perang terjadi, kelakuan manusia dipengaruhi oleh prasangka. Prasangka merupakan satu faktor yang dianggap mempengaruhi kelakuan manusia termasuk kelakuan dalam institusi pendidikan. Meskipun kajian ini tidak mengkaji kasus bunuh diri, namun teori anomik Durkheim dapat digunakan sebagai pisau analisa dalam kasus Aceh. Hal ini karena jika dilihat secara sosiologis, sesungguhnya konflik yang terjadi di Aceh telah membawa pengaruh pada integrasi sosial masyarakat di sana bahkan jika ditelusuri lebih jauh berdampak pada disintegrasi bangsa.

Keadaan anomik semacam ini dapat melanda seluruh masyarakat ketika terjadi perubahan secara cepat pada masyarakat tersebut, sementara di pihak lain masyarakat tersebut belum bisa menerima perubahan disebabkan karena belum dipahaminya nilai-nilai lama dengan baik serta belum jelasnya nilai-nilai baru. Situasi dalam era perang dalam kasus Aceh dapat dikatakan situasi anomik karena semuanya berlangsung dalam kekacauan. Namun apakah hal ini mempengaruhi interaksi sosial dalam ranah institusi pendidikan pada saat itu, akan dikaji lebih mendetil dalam pembahasan di bawah ini.

Selanjutnya, artikel ini juga menggunakan teori pertukaran Homans. Teori pertukaran digunakan untuk menganalis kondisi sosial di Aceh pasca-pergantian era (dari era perang ke era damai). Inti teori pertukaran Homans terletak pada sejumlah proposisi fundamental, yaitu bahwa manusia adalah makhluk sosial dan menggunakan sebagian besar waktu mereka untuk berinteraksi dengan manusia lain. Analisis dasar teori pertukaran Homans adalah pertukaran sosial antara

\footnotetext{
${ }^{6}$ Emile Durkheim, Suicide: A Study in Sosiology, terj. J. Simpson (London: Routledge dan Kegan Paul LTD, 1970), 14.

7 Anomik adalah keadaan moral di mana orang yang bersangkutan kehilangan citacita, tujuan dan terdapat gangguan terhadap norma dalam hidupnya. Nilai-nilai yang semula memberi motivasi dan arah kepada perilakunya tidak berpengaruh lagi sehingga menimbulkan kebimbangan pada diri seseorang. Lihat ibid., 46.
} 
dua individu dengan konsep prinsip-prinsip ekonomi. ${ }^{8}$ Dua orang individu yang mengadakan interaksi akan selalu mementingkan keuntungan dan meminimalisir kerugian. Dalam kondisi interaksi yang demikianlah rasionalitas digunakan.

Jadi, interaksi sosial adalah proses dasar di mana dua orang atau lebih menggunakan bahasa dan gerak anggota badan untuk saling mempengaruhi pikiran dan tingkah laku. Ketika berinteraksi seorang individu akan mengeluarkan informasi bukan saja dalam bentuk lisan, akan tapi juga melalui gerakan anggota badan. Selanjutnya, emosi dan kesan interaksi sosial dipertegas melalui tatap muka.

\section{Interaksi Guru dengan Orang Tua Siswa Era Perang}

Salah satu dampak peperangan adalah kehancuran harta benda manusia. Peperangan mengakibatkan masyarakat yang tidak bersalah kehilangan tempat tinggal. Mereka terpaksa mengungsi dan berusaha menghindari peperangan tersebut. Peperangan juga menyebabkan hilangnya peradaban dunia. Berbagai unsur dalam pembangunan budaya manusia yang menjadi kebanggaan manusia ikut musnah. Letusan-letusan bom telah mengakibatkan banyak unsur warisan budaya manusia seperti bangunan bersejarah dan sekolah hancur dengan sia-sia. Padahal unsur-unsur budaya manusia yang diwariskan perlu dijaga agar generasi mendatang mengetahui perkembangan budaya para pendahulunya.

Ketika perang berlangsung di Aceh, orang tua siswa dan guru menjalankan fungsi atau tanggungjawab yang sama terhadap pembangunan serta perkembangan kepribadian pelajar serta proses belajar mengajar. Mereka bertanggungjawab mendidik, mengajar, mengasuh, dan membimbing untuk membentuk masa depan pelajar yang sukses meskipun dalam tempat, waktu, dan keadaan yang berbeda. Hubungan anak dengan orang tua lebih kepada pertalian darah yang dipenuhi dengan kasih sayang, kemesraan, pengorbanan, dan rasa hormat. Ini memberi kelebihan kepada orang tua untuk berkomunikasi dengan anak secara langsung berbanding guru. Sementara itu, hubungan pelajar dengan guru lebih kepada aspek pendidikan formal dan menimba ilmu. Meskipun demikian, peranan guru dan orang tua siswa sama-sama sangat penting dalam usaha membentuk generasi masa depan yang baik.

8 George Ritzer dan Douglas J. Goodman, Teori Sosiologi Modern, terj. Alimandan (Jakarta: Prenada Media, 2004), 358.

${ }_{9}$ Abubakar, Panduan Kerja Guru Bestari (Kuala Lumpur: Seribu Dinar, 2004), 10. 
Pada era perang hampir semua aspek kehidupan berada di luar hukum normal. Peranan guru dalam mendidik pelajar di sekolah dan tanggung jawab orang tua dalam mendukung keberhasilan pendidikan anak-anak telah dimusnahkan oleh situasi lingkungan konfliktual. Dengan kata lain, peperangan secara langsung telah mempengaruhi interaksi antara guru dengan orang tua pelajar di Aceh. Hal ini dapat dilihat pada grafik berikut:

Grafik 1:

Interaksi Guru dengan Orang Tua Siswa

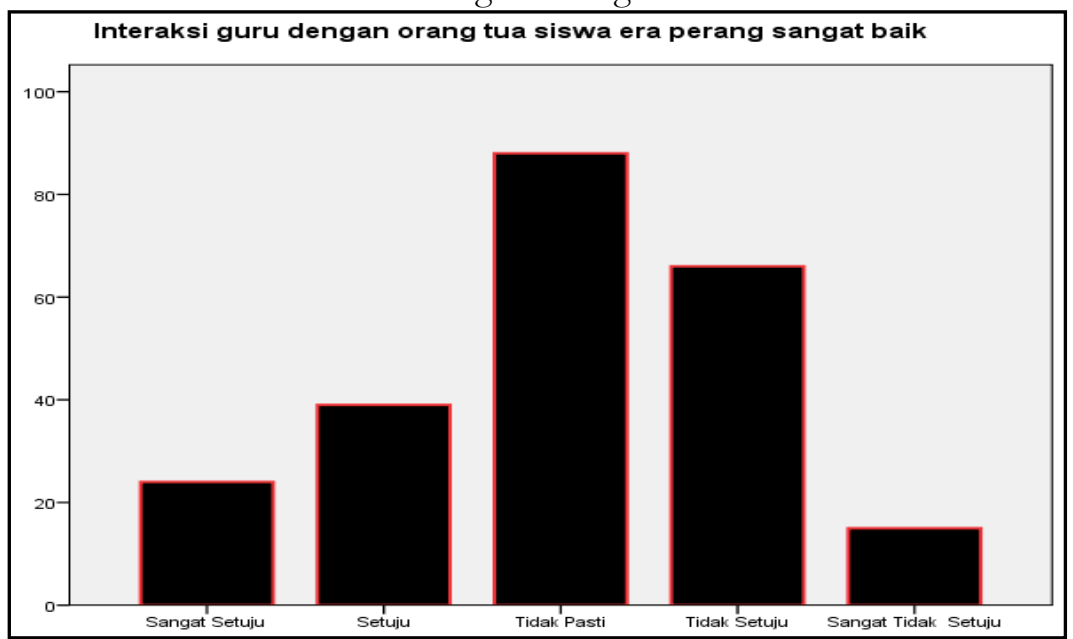

Sumber: Penelitian 2011

Data di atas menunjukkan bahwa 24 orang $(10.3 \%)$ responden menyatakan sangat setuju bahwa hubungan guru dengan orang tua siswa sangat baik pada era perang, 39 orang $(16,8 \%)$ responden menyatakan setuju, 88 orang $(37,9 \%)$ responden menyatakan tidak pasti, 66 orang $(28,4 \%)$ responden menyatakan tidak setuju dan 15 orang $(6,5 \%)$ responden menyatakan sangat tidak setuju jika dikatakan bahwa interaksi guru dengan orang tua pelajar sangat baik pada era perang. Oleh karena itu, kita dapat melihat dengan jelas bahwa interaksi sosial dalam institusi pendidikan terutama menyangkut hubungan guru dengan pelajar pada era perang mengalami berbagai persoalan.

Pada era perang terdapat orang tua pelajar yang berani melakukan intervensi terhadap guru di sekolah, terutama dalam pemilihan jurusan dan kenaikan kelas sampai kelulusan akhir. Keadaan ini telah menempatkan guru berada dalam posisi lemah karena guru yang selama ini memiliki wewenang penuh di sekolah telah ditentang oleh 
orang tua murid semenjak terjadinya peperangan di Aceh. Sebagai contoh di Madrasah Aliyah Negeri (MAN) di Aceh Timur pelajar hanya dapat memilih dua jurusan saja, yaitu jurusan Ilmu Pengetahuan Alam (IPA) dan jurusan Ilmu Pengetahuan Sosial (IPS).

Ketika orang tua siswa mendaftarkan anaknya ke sekolah, mereka meminta kepada guru agar anaknya ditempatkan di jurusan IPA. Padahal jika dilihat dari segi kemampuan akademis, menurut informan yang penulis wawancarai, anak tersebut hanya layak ditempatkan dalam jurusan IPS. Hal yang sama juga terjadi pada penentuan kelulusan akhir di mana intervensi orang tua terhadap guru, agar anaknya lulus, sangat kuat. ${ }^{10}$ Tingkat intervensi terhadap guru pada masa konflik di Aceh bisa dilihat dalam grafik berikut ini:

Grafik 2:

Intervensi Orang Tua Pelajar terhadap Guru

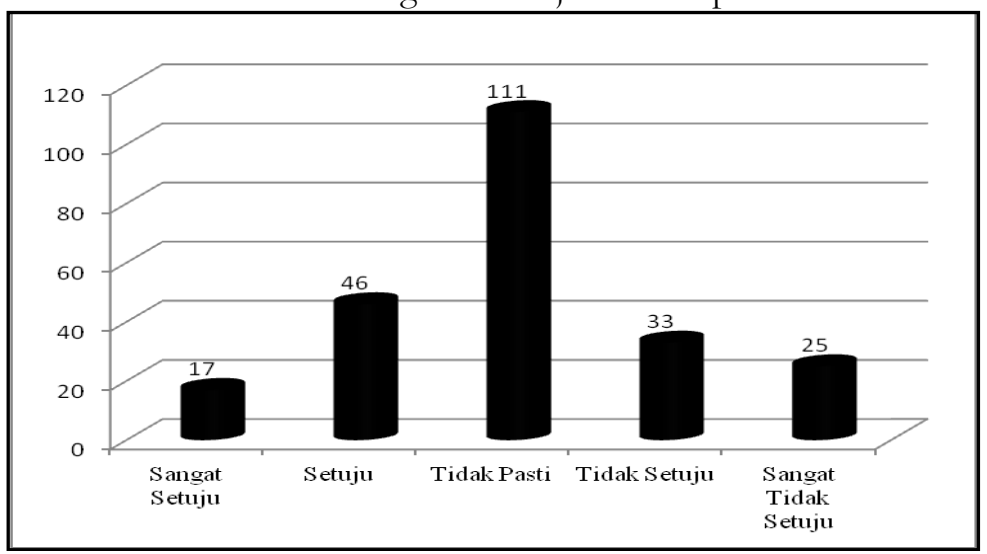

Sumber: Penelitian 2011

Data di atas menunjukkan bahwa 17 orang $(7,3 \%)$ responden menyatakan sangat setuju dengan pernyataan bahwa pada masa konflik orang tua pelajar berani mengintervensi guru, 46 orang $(19.8 \%)$ responden menyatakan setuju, 111 orang (47.8\%) responden menyatakan tidak pasti, 33 orang $(14.2 \%)$ responden menyatakan tidak setuju dan 25 orang $(10.8 \%)$ responden menyatakan sangat tidak setuju.

Kondisi pada saat itu memang telah membuat guru tidak dapat berbuat banyak di mana guru harus mempertimbangkan setiap permintaan dan pesan dari orang tua siswa. Meskipun anak yang dititipkan tidak layak untuk masuk di jurusan IPA, misalnya, tetapi

${ }^{10}$ Salwa, Wawancara, Idi Rayeuk, 19 Juli 2010. 
tetap saja mereka harus mendapat tempat di jurusan tersebut. ${ }^{11}$ Guru, dalam kasus ini, terpaksa meluluskan permintaan tersebut dengan persyaratan pelajar tersebut harus belajar lebih rajin dan giat agar dapat bersaing dengan pelajar lainnya. ${ }^{12}$

Lebih jauh, jika ada permasalahan yang terjadi antara guru dan siswa, pihak sekolah juga terpaksa menyimpan permasalahan tersebut dan tidak berani mengirimkan surat pemberitahuan kepada orang tua siswa. Hal itu karena surat resmi dari sekolah diharuskan menggunakan kertas berkop berlambang Departemen Agama (sekarang Kementerian Agama) Republik Indonesia. Sementara itu, lambang tersebut oleh GAM dianggap sebagai lambang Pemerintah Indonesia yang merupakan "musuh". Apabila terdapat hal yang harus disampaikan kepada orang tua murid, pihak sekolah terpaksa menyampaikannya secara lisan kepada pelajar yang bersangkutan untuk diteruskan kepada orang tuanya. Meskipun tidak ada jaminan bahwa pelajar tersebut akan menyampaikan berita itu kepada orang tuanya. ${ }^{13}$

Meskipun demikian, ada informan lain yang menyatakan bahwa guru sebenarnya tidak perlu takut dalam menegakkan peraturan di sekolah meskipun keadaan di Aceh tidak aman. Dalam keadaan seperti itu justru seharusnya guru bisa bertindak lebih tegas dalam menegakkan disiplin dan peraturan di sekolah. Terlibat atau tidaknya pelajar dalam kelompok GAM atau dalam pihak manapun tidak menjadi penghalang bagi ditegakkannya disiplin dan peraturan sekolah. Hal ini karena ketika berada di sekolah mereka adalah pelajar dan karenanya harus melepaskan semua atribut dan latar belakangnya. Guru juga harus berani menginformasikan kepada setiap orang tua murid jika anaknya melanggar disiplin dan peraturan sekolah. ${ }^{14}$

Informan tersebut bahkan menyontohkan bahwa anaknya pernah mengalami kegagalan di Sekolah Menengah Atas tahun 2009, namun ia tidak pernah menyalahkan guru dan pihak sekolah. Dia sepenuhnya sadar bahwa kegagalan anaknya tersebut murni karena kelalaian anak dikarenakan kemungkinan tidak mampu menjawab soal dalam ujian akhir di sekolah sehingga memperoleh nilai rendah dan faktor-faktor lain. Baginya, kegagalan dalam ujian akhir sekolah bukan berarti masa

\footnotetext{
11 Jurusan IPA menurut masyarakat setempat adalah jurusan favorit sehingga menjadi rebutan, karena anak-anak pintar akan ditempatkan di jurusan tersebut sementara jurusan lain seperti IPS kurang diminati.

12 Alfian, Wawancara, Gampong Jalan, 20 Juli 2010.

${ }^{13}$ Jafaryus, Wawancara, Peureulak, 21 Juli 2010.

${ }^{14}$ Sayed Ali, Wawancara, Keude Blang, Aceh Timur, 3 Agustus 2010.
} 
depan anaknya telah terkubur, karena Pemerintah telah menyediakan program ujian susulan bagi pelajar yang tidak lulus dalam ujian akhir secara nasional dengan istilah "Paket C". Oleh karena itu, menurut informan tersebut, tidak tepat jika orang tua menyalahkan pihak sekolah terutama guru jika anaknya kita tidak lulus ujian.

Informan di atas juga mengakui bahwa terdapat guru yang berstatus sebagai Pegawai Negeri Sipil (PNS) merasa takut kepada GAM karena berbagai alasan yang akhirnya mempengaruhi interaksi guru dengan orang tua murid. Hal ini karena guru tidak bisa memetakan dengan jelas mana orang tua pelajar yang mendukung perjuangan GAM atau sebaliknya. Akibatnya komunikasi antara guru dengan orang tua siswa terganggu.

Ilustrasi di atas secara teoretis menjelaskan bahwa keadaan anomik sepanjang berlakunya peperangan di Aceh sangat mempengaruhi interaksi antara guru dengan orang tua siswa. Hal ini karena guru berada di bawah tekanan dan ancaman. Mereka diintimidasi dan diperas dengan alasan pajak nanggroe.15 Bahkan ada orang tua siswa yang sengaja mempergunakan nama GAM di sekolah untuk menakuti guru. Perlu diketahui bahwa Aceh Timur merupakan salah satu wilayah yang memiliki basis kekuatan GAM terkuat di Aceh, terutama di Idi Rayeuek dan Peureulak, akan tetapi tidak semua orang tua siswa di tempat tersebut adalah anggota atau simpatisan GAM.

\section{Interaksi Guru dengan Orang Tua Pelajar Era Damai}

Salah satu dampak industrialisasi ialah berkurangnya fungsi keluarga dalam pendidikan. Institusi pendidikan formal telah mengambil alih fungsi keluarga bukan saja mengajar kemahiran khusus tetapi juga latihan yang bersifat normatif. Dengan kata lain, sekolah telah menjadi agen sosialisasi utama; Sekurangs-kurangnya ketika siswa berada di sekolah. Namun demikian, sekolah tidak bisa mengambil alih peranan tersebut sepenuhnya dari keluarga walaupun di negara industri maju. Keluarga tetap mempunyai pengaruh yang kuat. Oleh sebab itu, ahli-ahli sosiologi pendidikan telah memusatkan perhatian terhadap pengaruh tersebut.

Guru yang mengajar dalam kelas harus menjalankan tugas dengan penuh dedikasi dan bersikap profesional. Dalam mengajar, guru tidak

15 Pajak Nanggroe adalah uang yang diminta oleh kelompok Gerakan Aceh Merdeka (GAM) kepada Pegawai Negeri Sipil di Aceh termasuk guru. Uang tersebut dikumpulkan untuk operasional perjuangan GAM. Setelah Aceh damai pajak nanggroe tersebut sudah tidak ada lagi. 
boleh mengelompokkan siswa menurut suku, kelas sosial, latar belakang orang tua serta tidak membedakan bangsa mereka. Sebaliknya, setiap murid yang berlainan suku dan jenis kelamin ditempatkan dalam satu kelompok supaya peluang untuk mereka berinteraksi terbuka luas.

Model interaksi antara guru dengan orang tua murid pada era perang telah berubah setelah GAM berdamai dengan Pemerintah Indonesia. Cerita mengenai intervensi orang tua terhadap guru sudah tidak terdengar lagi. Cara-cara kekerasan dan intimidasi seperti pada masa konflik sudah tidak relevan lagi diterapkan pada era damai. ${ }^{16}$

Pada era damai guru sudah sering mengadakan pertemuan formal dengan orang tua siswa sehingga tercipta hubungan yang baik. Setiap tahun ajaran baru, para guru mengadakan pertemuan dengan orang tua siswa untuk menjelaskan sistem pengajaran dan pembelajaran yang berlaku di sekolah. Standar penilaian serta kurikulum yang berlaku di sekolah pun turut dijelaskan. Hasil penelitian menunjukkan bahwa terdapat perbedaan signifikan antara era perang dengan era damai di Aceh dalam hal peningkatan intensitas rapat/pertemuan antara guru dan orang tua murid di sekolah. Hal tersebut dapat dilihat pada grafik berikut:

\section{Grafik 3:}

Intensitas Rapat yang Dilakukan oleh Pihak Sekolah pada Era Perang dan Era Damai di Aceh

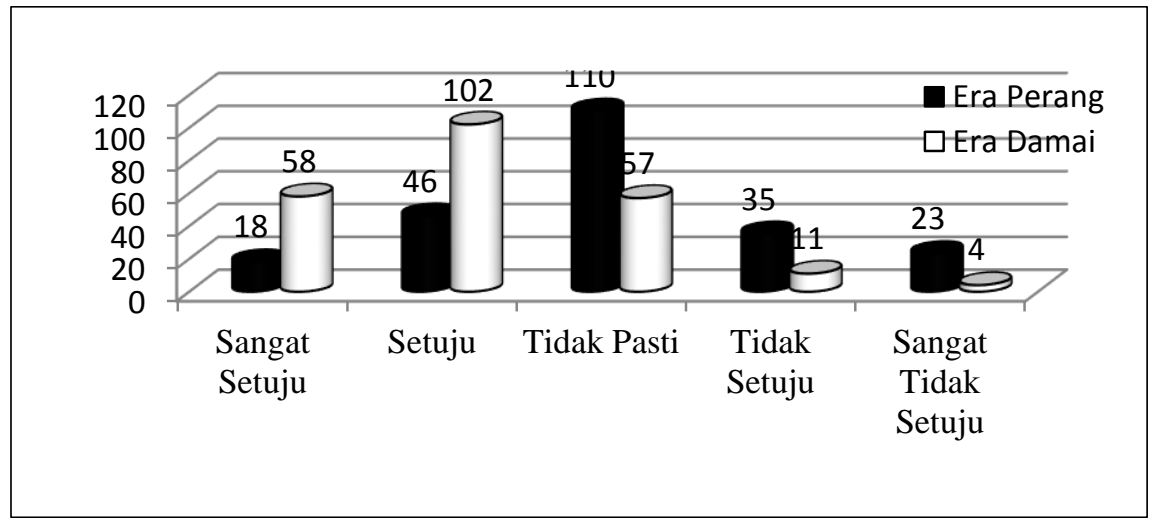

Sumber: Penelitian, 2011

Data di atas menunjukkan bahwa pada era perang sebanyak 18 orang $(7.8 \%)$ responden menyatakan sangat setuju diadakannya rapat antara guru dan orang tua siswa di sekolah, 46 orang $(19.8 \%)$

${ }^{16}$ Jafaryus, Wawancara, Peureulak, 21 Juli 2010. 
responden menyatakan setuju, 110 orang (47.4\%) responden menyatakan tidak pasti, 35 orang $(15.1 \%)$ responden menyatakan tidak setuju dan 23 orang $(9.9 \%)$ responden menyatakan sangat tidak setuju. Pada era damai, 58 orang $(25 \%)$ responden menyatakan sangat setuju diadakannya rapat antara guru dan orang tua siswa di sekolah, 102 orang $(44 \%)$ responden menyatakan satuju (mengalami peningkatan sebesar $24.2 \%$ daripada sebelum era damai), sebanyak 57 orang (24.6\%) menyatakan tidak pasti, 11 orang (4.7\%) menyatakan tidak setuju, dan hanya empat orang $(1.7 \%)$ yang menyatakan sangat tidak setuju.

Ketika pertemuan dengan orang tua siswa dilaksanakan pada awal tahun ajaran 2010/2011, misalnya, penulis melihat bahwa mereka dapat menerima aturan dan standar yang ditetapkan oleh sekolah. Ketika pihak sekolah menyediakan sesi tanya-jawab, tidak ada pertanyaan atau komentar yang berisi keberatan mengenai peraturan yang diterapkan oleh pihak sekolah. Bahkan ketika pihak sekolah meminta dana sumbangan untuk pembangunan mushalla sekolah, yang dibebankan kepada siswa dan diberikan setiap hari Jumat minggu pertama awal bulan, para orang tua siswa merasa tidak keberatan. Pihak sekolah menegaskan bahwa dana tersebut bersifat sedekah. Mushalla yang akan dibangun adalah untuk kemaslahatan semua siswa. Sekolah tidak menetapkan besaran jumlah yang harus dibayar oleh setiap pelajar, akan tetapi hal itu bergantung pada keikhlasan hati dan kemampuan ekonomi setiap orang tua murid.

Muhammad Iqbal, salah seorang pelajar MAN I di Aceh Timur, menyatakan bahwa kini para pelajar tidak berani sesuka hati memprotes guru terkait peraturan sekolah. Jika pelajar tidak mematuhi peraturan, guru dapat mengambil tindakan tegas terhadap pelajar tersebut, mulai dari peringatan hingga pemanggilan orang tua ke sekolah. Pelajar kini lebih disiplin dan patuh kepada peraturan sekolah. ${ }^{17}$

Harapan membangun pendidikan yang lebih baik memang akan terwujud hanya jika semua komponen yang terkait, termasuk masyarakat mendukung usaha tersebut. Saat ini di Aceh, perhatian orang tua terhadap pendidikan anak sudah tinggi. Hal ini dapat dilihat dari partisipasi orang tua siswa dalam pelaksanaan kegiatan-kegiatan di sekolah. Selain itu, dukungan orang tua dalam memotivasi pendidikan anak mereka sudah tampak. Banyak orang tua, misalnya, sanggup

${ }^{17}$ M. Iqbal, Wawancara, Idi Rayeuk, 20 Juli 2010. 
membelikan motor-meskipun dengan sistem kredit-untuk keperluan transportasi anak-anak mereka menuju ke sekolah demi mendukung keberhasilan pendidikan anaknya. ${ }^{18}$

\section{Pembangunan Pendidikan dan Perdamaian}

Setelah perang berakhir, Aceh-terutama Aceh Timur-terus memacu pembangunan dalam bidang pendidikan untuk mengejar ketertinggalan dari daerah lain di Indonesia. Masalah utama yang berkaitan dengan sarana dan prasarana pendidikan di Kabupaten Aceh Timur saat ini adalah kurangnya persediaan ruang kelas yang mampu menampung jumlah siswa secara proporsional. Masalah lain adalah keterbatasan jumlah tenaga pengajar dan lokasi penempatan sekolah yang belum merata jika dibandingkan dengan jumlah siswa dan jarak tempuh siswa ke sekolah.

Untuk pendidikan Sekolah Dasar (SD atau MIN) pemerintah kabupaten Aceh Timur telah membangun 315 buah sekolah yang menampung sekitar 59619 orang siswa di seluruh Kabupaten Aceh Timur. Idealnya, 1 ruang kelas menampung 30 murid. Kabupaten Aceh Timur hingga saat ini telah memiliki 4062 orang guru. Untuk Sekolah Menengah Pertama (SMP dan MTsN), pemerintah Kabupaten Aceh Timur telah membangun 78 buah sekolah dengan jumlah siswa saat ini sebanyak 20426 orang. Untuk tenaga pengajar sekolah menengah pertama, kabupaten Aceh Timur hingga tahun 2010 telah memilik 1584 orang guru. Sedangkan untuk Sekolah Menengah Atas (SMA, SMK dan MAN), pemerintah Kabupaten Aceh Timur telah membangun 36 unit sekolah untuk menampung 12.586 orang siswa. Guru sekolah menengah atas di seluruh Kabupaten Aceh Timur hingga tahun 2010 berjumlah 984 orang. ${ }^{19}$ Sementara itu sampai dengan tahun 2015 pembangunan pendidikan di Aceh Timur dapat dilihat pada tabel berikut:

Tabel 1:

Jumlah Sekolah, Kelas, Murid dan Guru di Aceh Timur

\begin{tabular}{|c|c|c|c|c|c|}
\hline Sekolah & $\begin{array}{c}\text { Jumlah } \\
\text { Sekolah }\end{array}$ & $\begin{array}{c}\text { Jumlah } \\
\text { Murid }\end{array}$ & Kelas & $\begin{array}{c}\text { Guru } \\
\text { PNS }\end{array}$ & $\begin{array}{c}\text { Guru non- } \\
\text { PNS }\end{array}$ \\
\hline TK & 64 & 2963 & 251 & 51 & 263 \\
\hline SD & 277 & 45644 & 2011 & 1786 & 1907 \\
\hline MI & 48 & 10701 & 411 & 433 & 313 \\
\hline
\end{tabular}

${ }^{18}$ Fadlisyah, Wawancara, Idi Rayeuk, 22 Juli 2010

${ }^{19}$ Dinas Pendidikan Aceh Timur, Laporan Tabunan, (2010). 


\begin{tabular}{|c|c|c|c|c|c|}
\hline SMP & 70 & 14152 & 1358 & 658 & 715 \\
\hline MTs & 27 & 8904 & 232 & 214 & 362 \\
\hline SMA & 26 & 7934 & 763 & 384 & 425 \\
\hline SMK & 11 & 2438 & 106 & 141 & 787 \\
\hline MAN & 14 & 3030 & 103 & 99 & 199 \\
\hline
\end{tabular}

Sumber: BPS Aceh Timur 2015

Prasarana pendidikan di Aceh Timur jika dibandingkan antara tahun 2005, 2010 dan 2015 telah mengalami peningkatan dari segi jumlah. Sekolah-sekolah yang dibakar pada masa konflik yang berada di bawah Departemen Agama maupun Dinas Pendidikan dan Kebudayaan sudah dibangun kembali oleh Pemerintah. Hal ini terlaksana berkat kerja sama antara semua pihak, yaitu: Pemerintah, masyarakat, pihak sekolah serta pihak keamanan.

Selain membangun prasarana fisik, pemerintah Aceh Timur juga menanamkan budaya damai kepada masyarakat. Dalam upaya menerapkan program pendidikan damai (peace education) kepada guru dan siswa di sekolah-sekolah, Pemerintah Kabupaten Aceh Timur bekerja sama dengan UNICEF. Peace education tersebut mengajarkan siswa tentang beberapa nilai penting perdamaian, seperti menerima diri, prasangka, perbedaan suku, perbedaan agama, jenis kelamin, status ekonomi, kelompok atau genetik, keanekaragaman, konflik, menolak kekerasan, mengakui kesalahan, dan memberi maaf. Dengan adanya program ini diharapkan akan tertanam nilai-nilai perdamaian dalam kehidupan masyarakat sekolah, khususnya di Aceh Timur. ${ }^{20}$

Untuk mewujudkan perdamiaan yang berkelanjutan, maka diperlukan perpaduan sosial dan peningkatan kapasitas kecerdasan sosial dalam masyarakat. Penguatan perpaduan sosial bertujuan menciptakan situasi di mana masyarakat memiliki kemampuan mencegah munculnya perilaku-perilaku atau intervensi yang memungkinkan terjadinya kekacauan dalam masyarakat sehingga dapat mengakibatkan masyarakat tidak mampu menjalankan tugasnya.

Sehebat apapun infrastuktur yang dibangun oleh Pemerintah hari ini di Aceh jika tidak disertai dengan kuatnya perpaduan sosial dan integrasi social, maka perdamaian tersebut akan hancur. Institusi sosial harus memainkan peranan dalam mewujudkan stabilitas sosial dalam masyarakat agar konflik tidak muncul lagi. Masyarakat berharap

20 Agussalim, Wawancara, Langsa, 16 Maret 2011. 
perdamaian yang sudah terajut dapat dijaga dan dipelihara untuk selamanya.

Kepaduan sosial bisa terwujud jika ada usaha sadar yang dimulai dari authority defined dan top down yang dapat melengkapkan dan menjamin kelangsungannya dan meningkatkan daya tahan dalam sebuah masyarakat. Salah satu usaha tersebut adalah pemantauan berkelanjutan melalui prosedur tertentu yang bertindak sebagai sistem peringatan awal (early warning system). Oleh karena itu, berbagai kemungkinan konflik terbuka yang akan terjadi dapat dideteksi dan dikontrol sebelum bereskalasi lebih besar dan merebak yang pada akhirnya justru merusak dan merugikan kohesi sosial yang telah wujud dengan baik. ${ }^{21}$

Keberagaman suku melahirkan berbagai perbedaan nilai, budaya, dan agama menjadikan setiap individu dalam kumpulan suku tertentu mempunyai pandangan yang berbeda dengan kumpulan suku yang lain. Persaingan dan konflik antarsuku, baik secara nyata atau diam-diam, sering terjadi di negara-negara yang berlatarbelakang masyarakat heterogen. Meskipun konflik yang terjadi di Aceh bukanlah konflik antarsuku, namun ia memberi kesan pada interaksi sosial antara suku Aceh dengan suku lain (non-Aceh) yang tinggal di Aceh selam konflik berlangsung, seperti yang telah dijalaskan dalam pendahuluan tulisan ini. Oleh karena itu, pembangunan menyeluruh sangat penting ditanamkan kepada masyarakat pada semua level. Hal ini bertujuan agar masyarakat dapat menjadikan perdamaian sebagai budaya dalam kehidupannya sehari-hari. Satu hal yang perlu digarisbawahi adalah bahwa interaksi sosial dalam masyarakat merupakan suatu isu yang penting dalam memupuk perpaduan bangsa.

\section{Interaksi Sosial dalam Bingkai Institusi Pendidikan}

Apabila integrasi sosial terganggu dalam suatu masyarakat, maka Pemerintah dapat mengambil tindakan tegas untuk mengontrol keadaan tersebut supaya tidak berdampak kepada disintegrasi bangsa. ${ }^{22}$ Situasi anomik selama peperangan di Aceh telah menyebabkan lahirnya situasi yang fatalistik dan altruistik sehingga interaksi sosial dalam

\footnotetext{
21 Shamsul Amri Baharuddin, Modul Hubungan Etnik (Bangi: Institut Kajian Etnik Universiti Kebangsaan Malaysia, 2012), 3.

${ }^{22}$ Kontrol sosial yang dimaksudkan di sini adalah cara dan proses pengawasan yang direncanakan dan tidak direncanakan yang bertujuan untuk mengajak, mendidik, bahkan memaksa warga masyarakat agar mematuhi norma dan nilai sosial yang berlaku.
} 
institusi pendidikan (pelajar dengan pelajar, pelajar dengan guru, guru dengan orang tua siswa), di Aceh pada era tersebut telah terganggu. Akan tetapi manakala perang berakhir, individu dalam masyarakattermasuk masyarakat Aceh-dapat bersosialisasi dan berinteraksi dengan baik.

Pada era perang di Aceh, aturan tidak dapat ditegakkan karena yang bermain adalah kekuasaan. Keadaan tersebut berlaku dalam masyarakat dan lingkungan sekolah. Ketika perang berlangsung, GAM memiliki wewenang dan kuasa untuk melakukan apa saja dalam masyarakat karena otoritas yang mereka miliki. Integrasi GAM sangat kuat dalam masyarakat dan integrasi pelajar sangat kuat dalam kelompok GAM. Hal ini melahirkan interaksi negatif dalam institusi pendidikan. Secara teoretis keadaan yang berlaku dalam institusi pendidikan di Aceh pada era perang mendukung pendapat Emile Durkheim dalam teorinya tentang anomik.

Durkheim, sebagaimana telah disinggung di atas, menyatakan bahwa penyebab bunuh diri adalah pengaruh dari terganggunya integrasi sosial. Peristiwa bunuh diri merupakan kenyataan sosial yang dapat dikaji dengan menghubungkan struktur sosial dan tingkat integrasi sosial dari suatu kehidupan. Apabila perang terjadi, kelakuan manusia dipengaruhi oleh prasangka/praduga. Prasangka sendiri merupakan salah satu faktor yang dianggap mempengaruhi kelakuan manusia termasuk kelakuan dalam institusi pendidikan. Pada era perang di Aceh, interaksi antara guru dengan orang tua siswa juga dipenuhi dengan prasangka. Integrasi sosial yang terganggu akibat konflik antara Gerakan Aceh Merdeka (GAM) dengan pemerintah Republik Indonesia pada saat itu telah mengganggu hubungan guru dengan orang tua siswa. Akibatnya, komunikasi antara guru dengan orang tua siswa terganggu.

Setelah Aceh damai interaksi antara guru dengan orang tua pelajar mengalami perubahan ke arah yang lebih baik. Dengan kata lain, perdamaian Aceh memainkan peranan penting dalam merubah pola interaksi dalam institusi pendidikan baik antara guru dengan orang tua siswa maupun antara guru dengan siswa. Orang tua siswa, guru dan para pelajar mulai berinteraksi tanpa perasaan takut dan tanpa disertai prasangka.

Dapat dikatakan bahwa pendidikan di Aceh, khususnya Aceh Timur, telah berubah ke arah yang lebih baik pada era damai. Keadaan yang tidak aman di daerah pedalaman pada masa perang telah berubah 
menjadi aman dan damai sehingga para guru dapat menjalankan tugasnya kembali dengan baik. Para pelajar yang dulu merasa takut untuk pergi ke sekolah, karena terancam jiwanya, saat ini sudah berani ke sekolah.

Para orang tua siswa yang dulu mengalami kesulitan mencari nafkah untuk membiayai pendidikan anak mereka saat ini sudah dapat bekerja dengan tenang tanpa disertai rasa takut. Komunikasi antara guru dengan orang tua siswa yang terganggu pada era perang saat ini telah terjalin kembali secara baik dan intensif. Banyak guru ketika era perang mengajukan mutasi dari Aceh Timur, karena keadaan konflik, saat ini sudah dapat bekerja dengan tenang dan tidak ada lagi yang mengajukan mutasi ke daerah lain yang aman. Secara umum dapat dikatakan bahwa pendidikan di Aceh Timur saat ini telah kembali ke jalurnya yang normal. Bagaimanapun kondisi damai merupakan faktor utama bagi terlaksananya proses belajar dengan baik dan sukses. ${ }^{23}$

Dengan hilangnya situasi anomik dan fatalistik, individu-individu yang saling berinteraksi mulai mengambil norma dan nilai ideal dalam masyarakat serta mempertimbangkan aspek keuntungan dari setiap interaksi yang mereka lakukan. Dengan terwujudnya perdamaian di Aceh, institusi pendidikan telah kembali memainkan peranan hakikinya, yaitu mendidik dan membimbing genenerasi muda Aceh.

Apabila perang berakhir maka situasi anomik juga berakhir. Dalam hal ini, teori pertukaran Homans dengan proposisi rasionalitasnya juga berlaku dalam interaksi antara guru dengan orang tua siswa di Aceh. Dalam era damai, fanatisme masyarakat terhadap GAM mulai menurun. Hal ini terjadi setelah masyarakat melihat, merasakan, dan menilai sendiri kinerja para mantan pejuang GAM baik di lembaga legislatif maupun eksekutif selama satu periode yang kurang memuaskan. Pada situasi inilah masyarakat Aceh memiliki pertimbangan mengenai aspek keuntungan dalam setiap interaksi yang mereka cetuskan. Disinilah pertimbangan mengani aspek untung rugi dengan konsep prinsip-prinsip ekonomi berlaku.

Ada beberapa faktor yang menjadi penyebab terjadinya perubahan interaksi sosial dalam institusi pendidikan di Aceh pada era damai. Pertama, tumbuhnya kesadaran tentang pentingnya pendidikan. Pemahaman tersebut menyebabkan pendidikan menjadi institusi terhormat karena masyarakat memerlukannya. Dampak positif turut dirasakan oleh guru yaitu dapat menjalankan tugasnya dengan baik.

${ }^{23}$ Faisal Hasan, Wawancara, Langsa, 17 Maret 2011. 
Ketika perang berlangsung, institusi pendidikan merupakan salah satu institusi sosial yang paling terdampak.

Lahirnya kesadaran akan pentingnya pendidikan dari semua pihak (guru, pelajar, masyarakat dan negara) menunjukkan bahwa semua pihak sudah dapat berpikir secara rasional dan meletakkan pendidikan di tempat yang sewajarnya. Jika hal ini dilihat dengan menggunakan teori perubahan maka proposisi rasionalitas (the rationality proposition) juga telah memainkan peranan yang sangat penting dalam mewujudkan interaksi harmoni dalam institusi pendidikan. Pelaku akan melakukan tindakan atau tidak tergantung pada persepsi mereka mengenai peluang kesuksesan. Orang yang ingin berhasil akan berpikir secara rasional dalam tindakannya apakah hal tersebut layak dilakukan atau tidak layak dilakukan. Dalam hal ini, rasionalitas diletakkan sebagai pertimbangan dalam menentukan setiap keputusan.

Kedua, perhatian Pemerintah RI terhadap institusi pendidikan sudah lebih baik. Pada era perang, Pemerintah tidak memandang serius terhadap pendidikan terutama nasib guru. Ada guru yang sudah bertahun-tahun mengabdi tetapi tidak mendapat perhatian dari Pemerintah untuk diangkat statusnya menjadi Pegawai Negeri Sipil (PNS). Namun saat ini hal tersebut telah berubah. Pemerintah memberi perhatian serius terhadap kesejahteraan guru, seperti pemberian tunjangan sertifikasi, gaji ke-tiga belas, dan uang makan.

Dalam aspek infrastruktur, Pemerintah juga telah memberikan perhatian yang serius terhadap bidang pendidikan di Aceh. Sebelum Aceh damai pembangunan infrastruktur pendidikan tidak dapat dilaksanakan karena adanya berbagai ancaman dari pihak GAM. Pada era damai perhatian negara terhadap pendidikan di Aceh semakin baik. Hal ini dibuktikan melalui besarnya anggaran dana yang dialokasikan oleh negara dalam sektor pendidikan di Aceh. Semua pihak turut merasakan manfaatnya. Sekolah yang dibakar pada era perang dapat dibangun kembali menggunakan dana tersebut. Jumlah dana yang banyak yang diperuntukkan bagi sektor pendidikan tidak saja telah menambah kesejahteraan guru, akan tetapi para siswa juga ikut menerima manfaat besar dengan adanya program beasiswa bagi siswa berprestasi namun lemah secara ekonomi. Bahkan siswa kurang mampu yang menjadi korban langsung konflik juga mendapat bantuan pendidikan dari pemerintah daerah yang diberikan setiap tahun.

Manfaat yang telah dirasakan oleh para guru dan pelajar di atas pada gilirannya juga dirasakan oleh para orang tua siswa. Orang tua 
siswa, khususnya yang memiliki keterbatasan dan kelemahan ekonomi, sangat menghargai bantuan dan perhatian Pemerintah tersebut. Bahkan para orang tua yang memiliki kecukupan ekonomi dan anak mereka berprestasi juga ikut merasakan manfaat, yaitu kemudahan dalam mengurus beasiswa bagi anak-anak mereka. Hal ini semakin mempertegas bahwa semua pihak mendapat manfaat dari perhatian negara terhadap institusi pendidikan melalui anggaran pendidikan yang tersedia. Jika hal ini dianalisis dengan menggunakan teori perubahan, maka proposisi nilai (the value of proposition) telah menyumbang ke arah perubahan interaksi dalam institusi pendidikan. Hal ini karena dengan diberikannya "hadiah" semisal uang $\mathrm{NAD}^{24}$, tunjangan sertifikasi, uang makan/lauk pauk, beasiswa bagi siswa berprestasi, beasiswa bagi siswa kurang mampu, dan bantuan korban konflik baik kepada guru maupun pelajar telah mengubah pandangan banyak pihak, khususnya masyarakat "pribumi" Aceh, terhadap Pemerintah Indonesia. Persepsi orang tua yang semula sinis, apatis, dan apriori-di mana mereka menganggap guru yang berstatus sebagai PNS hanya mengabdi untuk kepentingan Jakarta-menjadi lebih positif.

Ketiga, perang antara GAM dengan Pemerintah RI yang berlangsung selama hampir 30 tahun (1976-2005) telah membuat masyarakat Aceh merasa jenuh hidup dalam konflik. Mereka menyadari sepenuhnya bahwa tidak ada keuntungan yang diperoleh dari konflik yang sangat lama tersebut. Hanya kerugian yang dialami dalam hampir semua aspek kehidupan. Meminjam teori Homans di mana dia menyusun proposisi kerugian-kejemuan (the deprivation and satiation proposition) yang menjelaskan bahwa semakin besar keuntungan yang diterima seseorang sebagai hasil tindakannya, semakin besar kemungkinan ia melaksanakan tindakan itu. Model interaksi pada era konflik telah ditinggalkan dan digantikan dengan model interaksi yang baru yaitu interaksi era damai. Keuntungan yang diterima dari perubahan interaksi dalam institusi pendidikan pada masa damai semakin besar. Oleh karena itu, masyarakat yang sudah jenuh hidup dalam situasi konflik ingin mempertahankan model interaksi masa damai karena mereka telah membuktikan dan merasakan keuntungannya.

${ }^{24}$ Uang NAD yang dimaksudkan di sini adalah bantuan uang yang diberikan oleh Pemerintah Provinsi Aceh kepada guru yang bekerja di Aceh yang dialokasikan secara resmi dalam Anggaran Pendapatan dan Belanja Aceh (APBA). Namun program ini hanya sementara di mana begitu ada program tunjangan sertifikasi guru, bantuan uang NAD kepada guru dihapuskan. 
Keempat, sosialisasi damai yang dilakukan oleh Pemerintah Daerah bekerjasama dengan pihak sekolah dan lembaga swasta ternyata juga memberi dampak positif dalam mewujudkan interaksi sosial ke arah yang positif. Amanat perdamaian yang dilakukan oleh pihak sekolah melalui upacara dan nasehat sangat berguna dan memberi pengaruh nyata dalam mewujudkan perubahan di ranah institusi pendidikan.

Kelima, setiap individu dalam masyarakat ingin membina kehidupan baru. Perdamaian telah menciptakan stabilitas keamanan di Aceh. Institusi-institusi sosial telah bangkit dari kehancuran akibat perang. Masyarakat sudah jenuh hidup dalam konflik dan ingin menikmati kehidupan baru yang lebih baik. Guru, pelajar dan orang tua siswa telah memiliki persepsi yang sama dalam mewujudkan kehidupan berkualitas untuk kehidupan baru yang lebih baik di masa akan datang. Jadi, keadaan Aceh yang telah damai mendukung perubahan interaksi sosial ke arah yang baik. Nyanyian perang sabil untuk membakar semangat perjuangan dan patriotisme sudah tidak terdengar lagi. Bahkan mantan aktivis dan pejuang GAM pun ada yang sudah tidak hafal lagi dengan nyanyian hikayat perang sabil. Kini seluruh masyarakat Aceh ingin menikmati kehidupan baru yang penuh dengan kedamaian. Dalam ranah pendidikan para guru, siswa, dan orang tua melihat kejadian perang tidak mendatangkan keuntungan terhadap dunia pendidikan. Mereka telah memiliki komitmen bersama dan persepsi yang sama bahwa telah tiba masa bangkit untuk menikmati kehidupan baru dan meningkatkan mutu pendidikan di Aceh yang telah jauh tertinggal dari banyak daerah lain di Indonesia.

\section{Penutup}

Interaksi sosial merupakan hal penting dalam membentuk persatuan masyarakat dalam suatu negara. Interaksi yang baik di kalangan anggota masyarakat mewujudkan suasana yang menyenangkan dalam kehidupan bernegara dan bermasyarakat. Interaksi bermula dari tingkat individu kepada individu lain dan berkembang ke luar kepada komunitas yang lebih luas. Keharmonisan dalam interaksi bermula dari interaksi antara individu dan seterusnya berkembang kepada interaksi dalam kelompok. Penulis berkesimpulan bahwa perdamaian adalah kunci utama dalam mengubah pola interaksi dalam institusi pendidikan di Aceh.

Kehidupan selama era perang Aceh yang penuh dengan kecurigaan, kebencian, menghindari satu sama lain, brutal, dan kekerasan telah berubah pada era damai menjadi sebuah interaksi 
positif. Interaksi positif dimaksud adalah seperti adanya saling percaya satu sama lain, sikap santun, dan cinta damai. Nilai-nilai dalam interaksi positif tersebut tidak terkecuali merambah pada ranah institusi pendidikan, khususnya sekolah menengah atas di Aceh. Perubahan interaksi dalam institusi pendidikan di Aceh sendiri dicapai setelah melalui masa yang sangat panjang dan tantangan yang sangat berat. Kehidupan yang harmonis dapat terwujud karena jaringan sosial dalam institusi pendidikan, yaitu guru, pelajar, masyarakat, dan negara telah mengubah pola interaksi mereka. Hal ini tentunya dengan tidak mengabaikan aspek perdamaian yang lahir setelah pencapaian kata sepakat damai antara pemerintah Republik Indonesia (RI) dengan Gerakan Aceh Merdeka (GAM) di Helsinki Finlandia.

Apabila perang berakhir maka situasi anomik juga berakhir. Oleh karena itu, teori pertukaran Homans dengan proposisi rasionalitasnya berlaku dalam interaksi antara guru dengan orang tua siswa. Dalam era damai, fanatisme masyarakat terhadap GAM mulai menurun bahkan berangsur hilang. Pada era ini, individu yang saling berinteraksi mulai mempertimbangkan norma dan nilai dalam masyarakat serta mempertimbangkan aspek keuntungan dalam setiap interaksi yang mereka jalankan. Masyarakat Aceh saat ini telah memiliki kemampuan dan keberanian untuk memilih hal-hal yang terbaik bagi kehidupan mereka dan orang-orang yang mereka cintai, termasuk untuk anak-anak mereka. Mereka memberikan perhatian lebih kepada aspek pendidikan anak-anaknya. Para orang tua di Aceh menginginkan anak-anak mereka memiliki masa depan yang lebih baik.

\section{Daftar Rujukan}

Abubakar. Panduan Kerja Guru Bestari. Kuala Lumpur: Seribu Dinar, 2004.

Agussalim. Wawancara. Langsa, 16 Maret 2011.

Alfian. Wawancara. Gampong Jalan, 20 Juli 2010.

Ali, Sayed. Wawancara. Keude Blang, Aceh Timur, 3 Agustus 2010.

Alsagoff, Sharifah Alwiyah. Sosiologi Pendidikan. Petaling Jaya: Logman, 1988.

Baharuddin, Shamsul Amri. Modul Hubungan Etnik. Bangi: Institut Kajian Etnik Universiti Kebangsaan Malaysia, 2012.

Durkheim, Emile. Suicide: A Study in Sosiology, terj. J. Simpson. London:

Routledge dan Kegan Paul LTD, 1970.

Fadlisyah. Wawancara. Idi Rayeuk, 22 Juli 2010. 
Hamid, Ahmad Farhan. Jalan Damai Nanggroe Endatu: Catatan Seorang Wakil Rakyat Aceh. Jakarta: Suara Bebas, 2006.

Hasan, Faisal. Wawancara. Langsa, 17 Maret 2011.

Iqbal, M. Wawancara. Idi Rayeuk, 20 Juli 2010.

Jafaryus. Wawancara. Peureulak, 21 Juli 2010.

Ritzer, George dan Goodman, Douglas J. Teori Sosiologi Modern, terj. Alimandan. Jakarta: Prenada Media, 2004.

Saifuddin. Interaksi Sosial dalam Institusi Pendidikan Era Perang dan Damai di Aceh. Bangi: Universiti Kebangsaan Malaysia, 2013.

-----. Kesan Perang Terhadap Institusi Pendidikan. Bangi: Universiti Kebangsaan Malaysia, 2005.

Salwa. Wawancara. Idi Rayeuk, 19 Juli 2010. 